\title{
Hop 苦味成分の利用に関する研究
}

\author{
第 2 報 粉末忽布樹脂の製造及び Hop 中 \\ の硝酸加里について \\ 小武山温之* 得能喜久雄, 熊谷 吟造, \\ 原誠, 久保田素寬, 島田 敬太
}

\begin{abstract}
序
言

Hop の苦味を効果的に利用するために色々の力法が考兄られて来たが，著者の 合成麦酒では製造中の全 材料を粉末化することが目標であり，苦味成分の粉末化と平行して苦味の効果的利用を達成し，更にかさば る hop 銶果の運般と冷所貯蔵する費用の著しい節約を行なった。

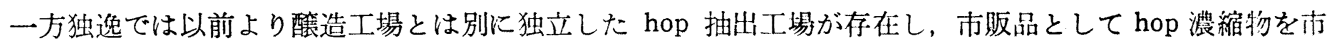
場に供給している。総説で述べた如くその場合 Resin の収媇は 72 \%であり損失は $28 \%$ \%゙ある。

著者は第 1 報汇述べた結果に基いて hop 粉末樹脂の製造方法を確立し, 実際に沖繩等に打ける麦酒原料 として工業的に実施した。以下製造方法について記述する。
\end{abstract}

\section{粉末 Hop 樹脂製造法}

\section{$\S 1$ Hop 樹脂の浸出}

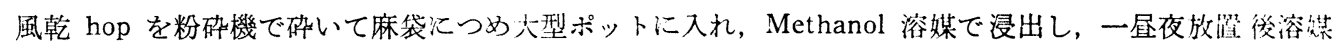
を更新する。この際麻袋は良く㩁り，出来るだけ麻袋こ Methanol と残さない。抽出は数回繰返すが最初 のポット中の抽出液は直ちに蒸溜機に入れて濃縮操作に移る。第 2 回目の抽出液の入ったポットには新しい hop をつめた麻袋を入れ一昼夜放置する。そして先の hop 垡恃次汇移行する。逐次このような連続的作業 にふり樹脂液を調製する。

\section{§ 2 Hop 樹脂液の粉末化}

前項のような方法で調製した樹脂液は蒸溜機で濃縮し，同時に溶媒を回収してゆく。この濃縮液をバット

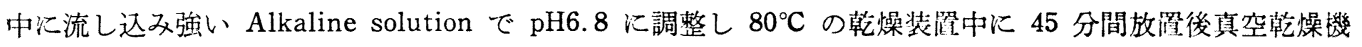
に移し $50{ }^{\circ} \mathrm{C}$ 以下で乾燥し湿気を進计て粉末化させる。

乾燥された濃縮物は Methanol を全く含まないものである。

\section{$\S 3$ 粉末 hop 樹脂の使用法}

上記のよ5にして製造された粉末 hop は湿気を避乩る容器に詰め椧所に保存する。煮沸麦汁に hopを沵 加する時の熱による樹脂損失を避けるため粉末 hop 樹脂は少量の酒精に溶した後酸酵前の麦汁に添加する。

\section{$\S 4$ 実験結果}

第 8 表 各樹脂量に於ける理論値と当法との比較

\begin{tabular}{|c|c|c|c|c|c|}
\hline & \multirow{2}{*}{$\frac{\text { 理 }}{\text { 風乾物中 }}$} & \multirow{2}{*}{$\frac{\text { 値 }}{\text { 無水物中 }}$} & \multicolumn{2}{|c|}{ 当彆造方法 } & \multirow[t]{2}{*}{ 収率 } \\
\hline & & & 風乾物中 & 無水物中 & \\
\hline 濃樎物重量 & & & $\left\{\begin{array}{l}24.2 \\
21.4\end{array}\right.$ & $\left\{\begin{array}{l}27.36 \\
23.94\end{array}\right.$ & \\
\hline 総 樹 脂 量 & 17.50 & 19.95 & $\left\{\begin{array}{l}16.6 \\
16.3\end{array}\right.$ & $\left\{\begin{array}{l}18.92 \\
18.92\end{array}\right.$ & $94.83 \sim 93.03$ \\
\hline 総靯樹脂量 & 6.28 & 7.15 & $\left\{\begin{array}{l}5.4 \\
5.2\end{array}\right.$ & $\left\{\begin{array}{l}6.15 \\
5.93\end{array}\right.$ & $86.11 \sim 82.92$ \\
\hline 総硬樹脂量 & 11.12 & 12.79 & $\left\{\begin{array}{l}11.4 \\
11.3\end{array}\right.$ & $\left\{\begin{array}{l}12.99 \\
12.88\end{array}\right.$ & $101.5 \sim 100.7$ \\
\hline
\end{tabular}

\section{§ 5 実地醇造比較試験}

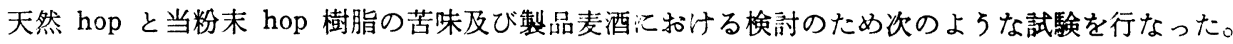
即ち糖化方法は Decortion 法洋い hop 添加後開放醊酵を 36 時間で終了後濾過し，桾類，アミノ酸,

* 国税庁醸造試験所 
有機酸を添加して, 次に $0^{\circ} \mathrm{C} て ゙ 12$ 時間冷却して濾過, 原液を造り, これに炭酸ガスと冷却水の混合した炭 酸水を注入，瓶詰，火入殺菌して製品とする。

仕込 1 ，は天然 hop を製品 $1 l$ 当り $4 \mathrm{~g}$ 使用したもの, 仕込 2 は当粉末 hop 樹脂 $0.96 \mathrm{~g}$ を使用したも のである。その結果仕込 2 の方が苦味力においても全体的な味の印象についても明らかに勝っていることが 見出された。当粉末樹脂は沖繩入重山群島石垣市新川に所在するゴールデンビヤー株式会社に㨟いて実際に 製造に使用した結果良好な製品が得られた。

\section{硝酸加里の検出}

Hop を Methanol 抽出し, これを蒸発する場合, 無色の針状結晶が器底にえられたので, これが何であ るかを娭討した結果硝酸加里であることが分った。この量は相当に多いので一応醴醉試験も行なった。

\section{§1 Hop 中の硝醊加里の決定}

乾燥 hop $10 \mathrm{~g}$ を採り, 蒸溜水 $100 \mathrm{ml}$ を加えて 1 時間煮沸し，これを濾過し，濃縮して残査には $100 \mathrm{ml}$ の蒸溜水を加えて再び煮沸する。このような操作を数回繰返してその都度最初の濾液に合せて, 濾液は濃縮 させ, $10 \mathrm{ml}$ 位になった時 Methenol を添加して濾過した。濾液は冷蔵庫で 12 時間放置すると, 白色針状 の結唱がえられたのでこれを滤別して Methanol で再結晶することを数回繰返して純品とした。

このものについて定性試験 (Dipenylamenesulfide 反応, 過塩素酸反応) 結晶形(針状)融点 $\left(333^{\circ} \mathrm{C}\right)$ 等に より硝酸加里であることを確認した。

尚，別個に行なった Frame photometer による加里の定量から，hop 中の硝酸加里の量は $\mathrm{K}_{2} \mathrm{O} 2.765 \%$ ごあったので硝酸加里としては $3.124 \%$ 入っていることが分る。

\section{麦酒醭母による硝酸加里の利用}

前述の如く hop 中には硝酸加里が含まれているが，これが躌醉をどの程度促進するものであるかを検べ た。

§ 1 硝酸加里添加による

培着基は数汁 (Balling 10) 飞それぞれ $0.0001 \% ， 0.0005 \%, 0.001 \%, 0.005 \%, 0.01 \%, 0.05 \%, 0.1$ \%になるように硝酸加里を添加し常法通り殺菌後, $100 \mathrm{cc}$ 当り, 予め培着した麦酒醅母 $0.1 \mathrm{cc}$ 宛添加して $30^{\circ} \mathrm{C}$ にて酸醉試験を行なった。各添加液について Balling の切れの程度を観察した。

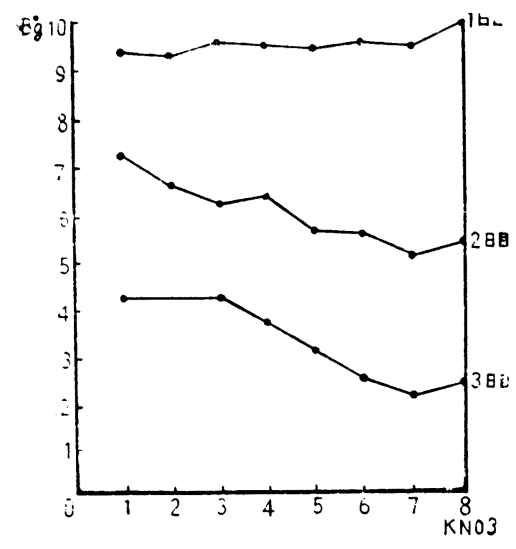

結

論

左図のようにいずれもContral の無添加と比較して Balling の切れは良好であり酵母の繁殖が促進されることが解る。従って メタノール等による忽布抽出物使用の場合は硝酸加里の欠減が考 えられるので醸酵液に硝酸加里を添加すべきであると考えられる。

\section{要}

約

1 Hop 樹脂の粉末化を行った結果収量 $24.2 \%$ 粉末製品を得 た。このものは Hop と殆んど同量に軟樹脂を含有している。

2 上記粉末樹脂製造中に得られた白色, 針状結晶について検 討した結果硝酸加里であることが解った。硝酸加里含量は hop 中 $3.124 \%$ \%ちった。 